\title{
A Timing Control of Cell Division in Escherichia coli
}

\author{
By M. A. DE PEDRO, J. E. LLAMAS AND J. L. CÁNOVAS \\ Instituto de Biología Celular, C.S.I.C., Velázquez I44, Madrid-6, Spain
}

(Received 17 March 1975; revised 2 June 1975)

\begin{abstract}
S UMMARY
The effect of heat treatment at $42{ }^{\circ} \mathrm{C}$ on a thermosensitive division-defective strain of Escherichia coli KI2, MACI, has been studied under conditions which support a generation time of about $50 \mathrm{~min}$. Synchronous cells gained simultaneously the ability to divide at $42{ }^{\circ} \mathrm{C}$ and to divide in the presence of nalidixic acid or chloramphenicol, $20 \mathrm{~min}$ before physical separation of daughter cells. When synchronous cells of different ages (between o and 20 min after elution from an absorbent membrane) were subjected to a heat shock, division always took place 55 to 60 min after the shock. A similar treatment of an exponential culture resulted in synchronous cell division after a lag of 55 to 60 min during which no division occurred. Division is probably controlled for 40 to $45 \mathrm{~min}$ by the gene mutated in MACI. Thus MACI cells of different ages appear to return to the same point of their division cycle when they are heated at $42{ }^{\circ} \mathrm{C}$. We propose that the gene mutated in MACI has a role in the timing control of $E$. coli cell division. Progress to division appears to require a fixed period in which the function controlled by the gene is performed; this period ends, under physiological conditions, when division does not require further protein or DNA synthesis.
\end{abstract}

\section{INTRODUCTION}

Chromosome replication and cell division are intimately connected processes in Escherichia coli. Under normal conditions completion of a round of replication is a necessary prerequisite for division (Clark, 1968; Helmstetter \& Pierucci, 1968). A protein(s) whose synthesis is dependent on the replication of the chromosome terminus, appears to be required for subsequent division of the cell (Jones \& Donachie, 1973). It has been proposed that its role is to release the chromosomal DNA from its attachment to the cell membrane which is necessary for subsequent cell division (Jones \& Donachie, 1974).

The chromosome replication cycle could provide the clock for division. However, the following facts strongly suggest that the timing of cell division is controlled by additional systems which are more or less independent of DNA replication. Firstly, under many growth conditions (I to 3 generations/hour) the interval between the termination of chromosome duplication and division is constant (20 $\mathrm{min}$ ) (Cooper \& Helmstetter, 1968). Secondly, at doubling times between 27 and $45 \mathrm{~min}$ a fixed period of protein synthesis, which normally occurs concurrent with chromosome replication but can be uncoupled from it, is required for division (Pierucci \& Helmstetter, 1969). The nature of the timing control systems of cell division is still unknown. The properties of a division-defective strain of $E$. coli are described, showing that it is affected in a gene which appears to be involved in the timing control of cell division. 


\section{METHODS}

Bacteria. The mutant, MACI, used throughout this work was a thermosensitive, str-r derivative of MC6 (source: M. G. Chandler), Escherichia coli $\mathrm{KI}_{2} \mathrm{~F}^{-}$thy A dra drm thi thr leu proC. Mutant MACI was isolated from Mc6 after mutagenesis with $N$-methyl- $N^{\prime}$-nitro- $N$ nitrosoguanidine following the method of Cerdá-Olmedo, Hanawalt \& Guerola (I968). Survivors were grown at $30^{\circ} \mathrm{C}$ and screened on LB medium (see below) for inability to form colonies at $42{ }^{\circ} \mathrm{C}$. The temperature-sensitive mutants were then screened for ability to grow, as indicated by the absorbancy increase of their cultures, and for ability to form filaments at the non-permissive temperature. Mutant MACI was a spontaneous str-r (able to form colonies in the presence of $200 \mu \mathrm{g}$ streptomycin $/ \mathrm{ml}$ ) derivative of one of these mutants. Strain LEI 35 (source: R. H. Pritchard), E. coli $\mathrm{KI} 2 \mathrm{Hfr} \mathrm{C}$ thi met, was used in mating experiments.

Media and conditions of cultivation. LB medium containing $10 \mathrm{~g}$ tryptone, $5 \mathrm{~g}$ yeast extract, I $\mathrm{g} \mathrm{NaCl}$, I $\mathrm{g}$ glucose and $2.5 \mathrm{mg}$ thymine per litre distilled water, was used in most of the experiments. MA medium was M9 synthetic medium (Adams, 1959) supplemented with thiamine $(2 \mu \mathrm{g} / \mathrm{ml})$, thymine $(2.5 \mu \mathrm{g} / \mathrm{ml})$, Casamino acids $(200 \mu \mathrm{g} / \mathrm{ml})$ and the following amino acids, each at $40 \mu \mathrm{g} / \mathrm{ml}$ : threonine, leucine and proline. The nutrient broth was $2.5 \%(\mathrm{w} / \mathrm{v})$ Oxoid No 2 . Media were solidified with $\mathrm{I} \cdot 5 \%(\mathrm{w} / \mathrm{v})$ agar for plating purposes.

Liquid medium was inoculated from a previous culture to an initial extinction of about 0.01 and aerated at $30^{\circ} \mathrm{C}$ in a New Brunswick gyratory water bath.

Mass and cell number determinations. Extinctions of cultures were measured at $450 \mathrm{~nm}$ with a Gilford microsample spectrophotometer using a $10 \mathrm{~mm}$ light-path. Particles were counted with a model ZBI Coulter counter after dilution in $0.9 \%(\mathrm{w} / \mathrm{v}) \mathrm{NaCl}-0.4 \%(\mathrm{w} / \mathrm{v})$ formaldehyde. Viable cells were measured in samples suitably diluted in 0.I M-phosphate buffer $\mathrm{pH} 6.8$ and spread on to agar plates.

$D N A$ assays. Cultures were grown for at least five generations at $30^{\circ} \mathrm{C}$ on MA supplemented with $\left[{ }^{3} \mathrm{H}\right]$ thymine $(0.05 \mu \mathrm{Ci} ; 2.5 \mu \mathrm{g} / \mathrm{ml})$ and deoxyguanosine $(100 \mu \mathrm{g} / \mathrm{ml})$ (Kammen, 1967), and experimental treatments carried out as indicated. Radioactivity present in the acid-insoluble fraction was determined by adding I $\mathrm{ml}$ samples to an equal volume of cold (0 to $4{ }^{\circ} \mathrm{C}$ ) trichloroacetic acid $(10 \%, \mathrm{w} / \mathrm{v})$; after $2 \mathrm{~h}$ they were membrane filtered (Whatman filter $\mathrm{GF} / \mathrm{F}, 25 \mathrm{~mm}$ diameter) and washed six times with $5 \mathrm{ml}$ of hot ( 90 to $95{ }^{\circ} \mathrm{C}$ ) distilled water. The filters were dried at $42{ }^{\circ} \mathrm{C}$ for $\mathrm{I} 2 \mathrm{~h}$ and placed in small glass vials containing $2.5 \mathrm{ml}$ of scintillation fluid [0.5\%, v/v, 2-(4'-t-butylphenyl)-5-(4"-biphenyl)-I ,3,4-oxadiazole in toluene]. The vials were placed in standard scintillation vials and counted in a NuclearChicago MK-I I liquid scintillation counter.

Interrupted matings. Male bacteria (LEI 35) were grown on nutrient broth, without aeration, at $37^{\circ} \mathrm{C}$ to a concentration of about $2.0 \times 10^{8}$ viable cells $/ \mathrm{ml}$. Recipient (MACI) was grown, with shaking, at $30^{\circ} \mathrm{C}$ to $2.0 \times 10^{8}$ viable cells $/ \mathrm{ml}$. They were mixed in a ratio of I Hfr :5 $\mathrm{F}^{-}$and incubated at $34{ }^{\circ} \mathrm{C}$. Samples $(0.2 \mathrm{ml})$ were removed at I min intervals, diluted with $\mathrm{I} \cdot 8 \mathrm{ml}$ of $0 . \mathrm{I} \mathrm{M}$-phosphate buffer $\mathrm{pH} 6.8$, violently agitated for $\mathrm{I} 0 \mathrm{~s}$ on a saber saw (Low \& Wood, I965), and plated $(0.5 \mathrm{ml})$ on prewarmed agar plates.

Synchronous growth. Synchronous cultures were obtained by the membrane elution technique as modified by Cummings ( 1970$)$. Samples $(200 \mathrm{ml})$ of a culture in exponential growth $\left(5 \times 10^{7}\right.$ viable cells $\left./ \mathrm{ml}\right)$ on $\mathrm{LB}$ medium at $30^{\circ} \mathrm{C}$ were filtered on to the surface of a BDWPtype $(0.6 \mu \mathrm{m}$ pore size, $142 \mathrm{~mm}$ diameter) Millipore membrane filter. The filter was inverted and elution with LB medium, at a rate of $20 \mathrm{ml} / \mathrm{min}$, was begun. The elution rate was changed $30 \mathrm{~min}$ later to $10 \mathrm{ml} / \mathrm{min}$, and after another $30 \mathrm{~min}$ samples ( $15 \mathrm{ml}$ ) were collected and placed in a shaker water bath. All these operations were carried out in a room at $30{ }^{\circ} \mathrm{C}$. 
Temperature shifts. Temperature shifts from 30 to $42{ }^{\circ} \mathrm{C}$ were achieved by immersing cultures ( $15 \mathrm{ml}$ volume in $50 \mathrm{ml}$ growth flasks) in a water bath shaker at $45^{\circ} \mathrm{C}$ for $30 \mathrm{~s}$ and then in another shaker at $42{ }^{\circ} \mathrm{C}$. The time for the attainment of thermal equilibration was $50 \mathrm{~s}$. The same method was used to change the temperature from 42 to $30^{\circ} \mathrm{C}$, but using an ice water bath shaker in which the culture was immersed for $7 \mathrm{~s}$ before being transferred into a second shaker at $30^{\circ} \mathrm{C}$; thermal equilibration was achieved in $15 \mathrm{~s}$.

\section{RESULTS}

\section{Phenotypic and genetic analysis of strain MACI}

The thermosensitive mutant MACI did not form colonies at $42{ }^{\circ} \mathrm{C}$ but was able to grow at this temperature as indicated by increasing $E_{450}$ (Fig. I). Exponential growth of MACr continued at $42{ }^{\circ} \mathrm{C}$ for at least $3 \mathrm{~h}$. Exponential DNA synthesis also continued at $42{ }^{\circ} \mathrm{C}$ for more than $2.5 \mathrm{~h}$ and the increase in DNA was about 4- to 5-fold (Fig. I). The mutant could initiate rounds of chromosome replication at the restrictive temperature, as indicated by its ability to synthesize DNA at $42{ }^{\circ} \mathrm{C}$ after amino acid starvation at $30^{\circ} \mathrm{C}$ for a period exceeding one generation time. When the temperature was raised from 30 to $42{ }^{\circ} \mathrm{C}$, MACI cultures stopped increasing in particle number after about $20 \mathrm{~min}$. These properties characterize MACI as a conditional division-defective strain.

The thermosensitive mutation of MACI mapped between thr and proC, at $3 \pm \mathrm{I}$ min on the genetic map (Taylor \& Trotter, 1972).

\section{Effect of heat shocks on synchronous cultures of MACI}

Synchronous cells were selected as described. Their generation time under these conditions was approximately $50 \mathrm{~min}$, as calculated from the interval between the two first rounds of division. The mass doubling time of MACI exponential cells growing on LB medium at $30{ }^{\circ} \mathrm{C}$ was also $50 \mathrm{~min}$. However, the first round of division of synchronous cells took place 40 to 45 min after elution from the membrane.

The incubation temperature of synchronous cultures of MACI was shifted from 30 to $42{ }^{\circ} \mathrm{C}$ at different times after elution and particle numbers counted (see Fig. 3). Division became resistant to the increased temperature between $2 \mathrm{I}$ and $24 \mathrm{~min}$ after cell elution, about $20 \mathrm{~min}$ before the actual time at which division took place ( 42 to $43 \mathrm{~min}$ ). In another experiment, division became resistant to $42{ }^{\circ} \mathrm{C} 24$ to $27 \mathrm{~min}$ after elution, when the division time was 46 to $47 \mathrm{~min}$. The ability to divide at $42{ }^{\circ} \mathrm{C}$ was acquired by MACI cells at the same time that no further protein or DNA synthesis was required for division (see Fig. 5). The shortest time after cell elution at which chloramphenicol (CAP) could be added to a synchronous culture without totally inhibiting cell division was between $2 \mathrm{I}$ and $24 \mathrm{~min}$, the same time as that at which division became resistant to $42{ }^{\circ} \mathrm{C}$. Similar results were found when nalidixic acid (NA), an inhibitor of DNA synthesis, was used. Both CAP and NA partially inhibited cell division when added 20 min before the time of the division round (Fig. 5). This was not due to synchrony deficiencies, because the same degree of inhibition was found when CAP and NA were added 30 and $33 \mathrm{~min}$ after cell elution. Figure 4 shows an experiment in which synchronous cultures were subjected to a Io min heat shock at $42{ }^{\circ} \mathrm{C}$ to inactivate the product of the gene mutated in MACI (we have tentatively called this gene $\operatorname{div} A$ ). The heat shock was started at varying times after elution. The round of division took place in all cultures at the same time, about $55 \mathrm{~min}$ after the shift-down. The expected maximum division time for the oldest cells used in this experiment was $25 \mathrm{~min}$, and $45 \mathrm{~min}$ for the youngest cells. These 


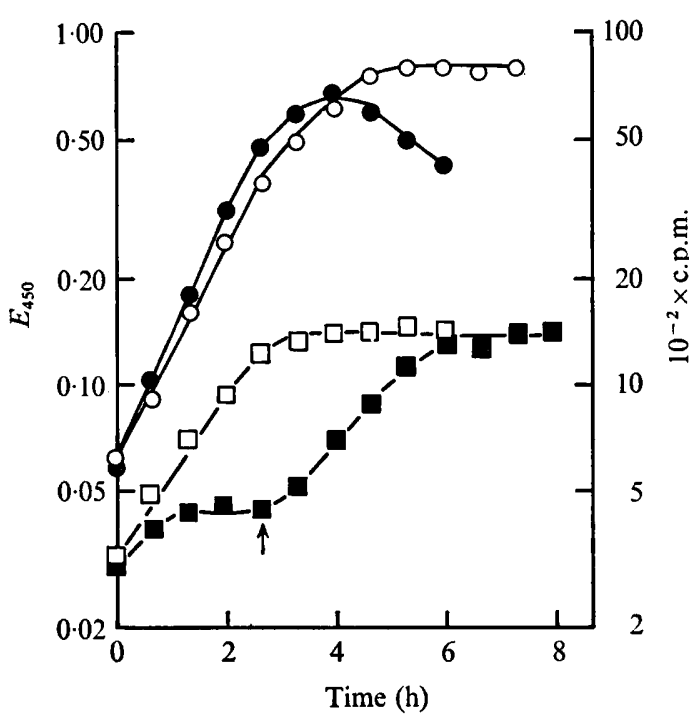

Fig. I

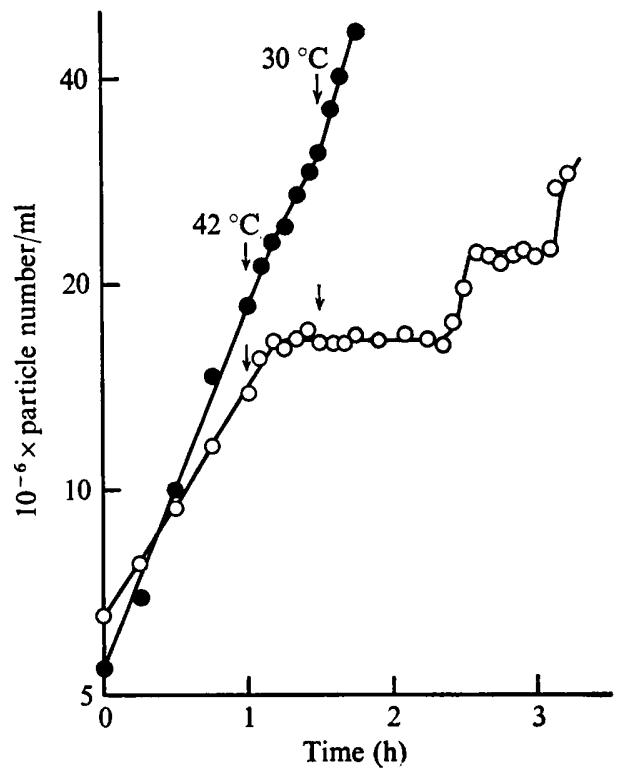

Fig. 2

Fig. I. Growth and DNA synthesis in strain MACI. Extinction was followed in MA (O) or LB (O) media after the culture was shifted from $30{ }^{\circ} \mathrm{C}$ to $42{ }^{\circ} \mathrm{C}$. In measuring $\left[{ }^{3} \mathrm{H}\right.$ ] thymine incorporation, one culture ( $\square$ ) was shifted to $42{ }^{\circ} \mathrm{C}$ and radioactivity present in the acid-insoluble fraction was determined at intervals in I ml samples. A second culture ( $\square$ ) was filtered (Millipore HAWP filter, $0.45 \mu \mathrm{m}$ pore size, $47 \mathrm{~mm}$ diameter), the cells washed twice with MA plus the labelling mixture but without amino acids, and resuspended in this medium. The suspension was incubated at $30{ }^{\circ} \mathrm{C}$; at the time indicated by the arrow, temperature was shifted to $42{ }^{\circ} \mathrm{C}$ and amino acids were added.

Fig. 2. Effect of temperature shifts on cell division in exponential cultures of MACI and the parental strain MC6. Cultures were incubated on LB medium at $30^{\circ} \mathrm{C}$ and, at the time indicated by the arrows, they were shifted to $42{ }^{\circ} \mathrm{C}$ and returned to $30^{\circ} \mathrm{C}$. $\bigcirc$, strain MACI; 9 , MC6.

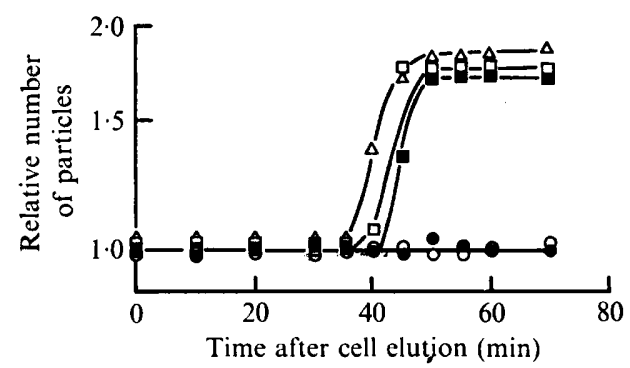

Fig. 3

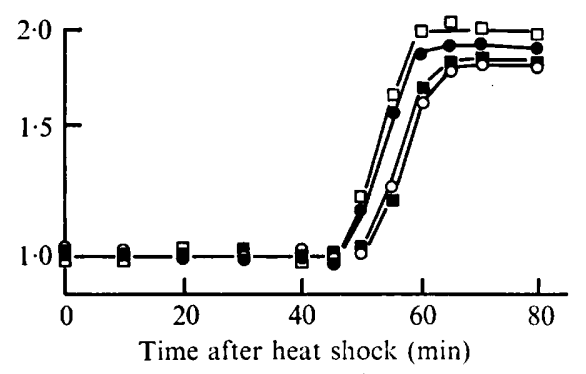

Fig. 4

Fig. 3. Division of MACI at $42{ }^{\circ} \mathrm{C}$. Synchronous cultures at $30^{\circ} \mathrm{C}$ in LB medium were shifted to $42{ }^{\circ} \mathrm{C}$, at $\mathrm{I} 8(\bigcirc), 2$ I $(\bigcirc), 24(\square)$ and $27(\square)$ min after cell elution from the membrane. A control culture $(\triangle)$ was not shifted to $42{ }^{\circ} \mathrm{C}$. Particle counts $/ \mathrm{ml}$ at o min were about $5 \times 10^{5}$.

Fig. 4. The effect of heat shock on MACI synchronous cells of different ages. Synchronous cultures growing in LB medium at $30^{\circ} \mathrm{C}$ were subjected to 10 min heat shocks at $42{ }^{\circ} \mathrm{C}$ starting $(\square) 0,(\square) 5$, (O) 10 and (O) $20 \mathrm{~min}$ after cell elution from the membrane. Initial particle counts $/ \mathrm{ml}$ were $2.4 \times 10^{5}$ $(\square, 0,0)$ and $2.6 \times 10^{5}(\square)$. 


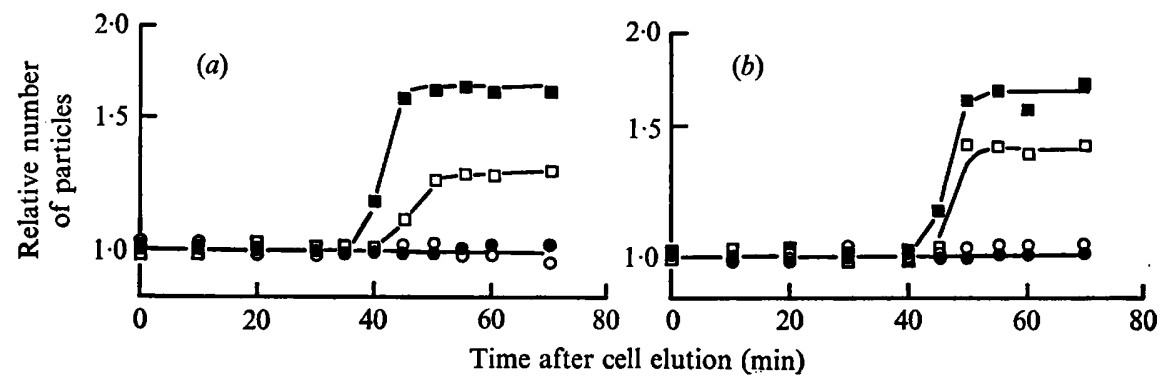

Fig. 5. Comparison of cell division at $42{ }^{\circ} \mathrm{C}$ with division in the presence of CAP or NA in strain MACI. (a) CAP $(200 \mu \mathrm{g} / \mathrm{ml})$ was added to synchronous cultures at $30^{\circ} \mathrm{C}$ in $\mathrm{LB}$ medium at varying times after elution. An identical culture was shifted to $42{ }^{\circ} \mathrm{C}$ at similar times. $O$, CAP added at 2I min; $O$, shifted to $42{ }^{\circ} \mathrm{C}$ at $2 \mathrm{I} \mathrm{min;} \square$, CAP added at $24 \mathrm{~min}$; $\square$, shifted to $42{ }^{\circ} \mathrm{C}$ at $24 \mathrm{~min}$. Initial particle counts $/ \mathrm{ml}$ were $3.8 \times 10^{5}(O, O)$ and $3.0 \times 10^{5}(\square, \square)$. (b) As (a) but using NA $(80 \mu \mathrm{g} / \mathrm{ml})$ instead of CAP. $\bigcirc$, NA added at $24 \mathrm{~min}$;, shifted to $42{ }^{\circ} \mathrm{C}$ at $24 \mathrm{~min} ; \square, \mathrm{NA}$ added at $27 \mathrm{~min} ; \mathrm{\square}$, shifted to $42^{\circ} \mathrm{C}$ at $27 \mathrm{~min}$. Initial particle counts $/ \mathrm{ml}$ were $2.4 \times 10^{5}(\mathrm{O}, \mathrm{O})$ and $2 \cdot \mathrm{I} \times 10^{5}$ $(\square, \boldsymbol{\square})$.
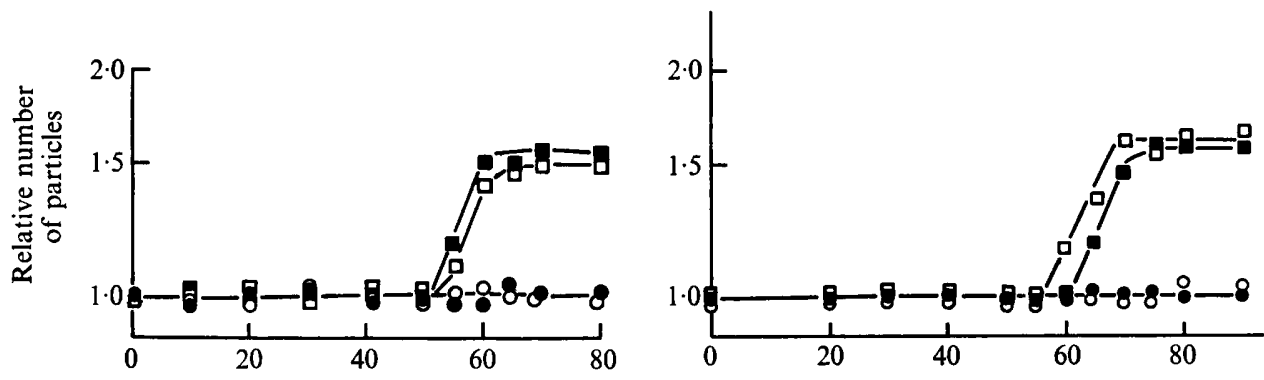

Fig. 6

Fig. 7

Fig. 6. Acquisition of the ability to divide at $42^{\circ} \mathrm{C}$ by synchronous MACI cells previously subjected to heat shock. Heat shock ( $10 \mathrm{~min}$ at $42{ }^{\circ} \mathrm{C}$ ) immediately after elution was followed by incubation at $30^{\circ} \mathrm{C}$ for $(\bigcirc) 40$ or $(\square) 45$ min before shifting to $42{ }^{\circ} \mathrm{C}$. Heat shock 20 min after elution was followed by incubation at $30^{\circ} \mathrm{C}$ for (O) 40 or (a) $45 \mathrm{~min}$ before shifting to $42{ }^{\circ} \mathrm{C}$.

Fig. 7. Acquisition of the ability to divide in the presence of CAP by synchronous MACI cells previously subjected to heat shock. Synchronous cultures growing at $30^{\circ} \mathrm{C}$ on LB medium were subjected to a $20 \mathrm{~min}$ heat shock at $42{ }^{\circ} \mathrm{C}$ starting $20 \mathrm{~min}$ after elution; they were returned to $30^{\circ} \mathrm{C}$ and CAP $(300 \mu \mathrm{g} / \mathrm{ml})$ was added $(\bigcirc) 30,(O) 35,(\square) 40$ and $(\square) 45$ min later. Initial particle counts/ $\mathrm{ml}$ were $3.9 \times 10^{5}(O, O, \square)$ and $3.6 \times 10^{5}(\square)$.

results indicate that heated cells apparently return to the same point of their division process regardless of age.

To investigate the total time in which division is controlled by $\operatorname{div} A$, an experiment similar to that shown in Fig. 3 was carried out but using cells in which the $\operatorname{div} A$ product had been previously inactivated (by a 10 min shock at $42{ }^{\circ} \mathrm{C}$ ) either at the time of elution or 20 min later. In both cases the ability to divide at $42{ }^{\circ} \mathrm{C}$ was acquired between 40 and $45 \mathrm{~min}$ after the end of the previous heat shock (Fig. 6). This is probably the length of the $\operatorname{div} A$ control period. The thermosensitivity of the product of $\operatorname{div} A$ expression suggested that it was a protein. To confirm this point and to determine the expression time of the gene, synchronous cultures were shifted to $42{ }^{\circ} \mathrm{C} 20 \mathrm{~min}$ after cell elution and incubated at this temperature for another $20 \mathrm{~min}$. This length of time (a total of $40 \mathrm{~min}$ after cell elution) should be enough for cells to complete the round of DNA replication and protein synthesis necessary for division (see Fig. 5). The cultures were then returned to $30^{\circ} \mathrm{C}$ and CAP was added at various times. 
Addition of CAP at any time up to 40 min after the heat shock prevented cell division (Fig. 7). The protein that had to be synthesized under our experimental conditions was probably the thermosensitive $\operatorname{div} A$ product, because cells were able to divide when CAP was added $24 \mathrm{~min}$ after cell elution if they had not been subjected to the heat shock (Fig. 5). The protein synthesis period controlled by $\operatorname{div} A$ was completed between 35 and $40 \mathrm{~min}$ after the heat shock, that is, about 5 min before the end of the period in which division was controlled by $\operatorname{div} A$.

\section{Effect of heat shocks on exponential cultures of MACI}

From the data obtained with synchronous cultures, at least three predictions can be made on the effect of heat shock at $42{ }^{\circ} \mathrm{C}$ on exponential cultures of MACI : Firstly, after a shift-up from 30 to $42{ }^{\circ} \mathrm{C}$ there must be residual divisions for about $20 \mathrm{~min}$ to produce an increase in cell numbers of approximately $30 \%$. This is based on the fact that cells in the last $20 \mathrm{~min}$ of the cell cycle (which lasts $50 \mathrm{~min}$ ) are resistant to heating (Fig. 3). The percentage of residual divisions was calculated from these data by considering the cell number distribution throughout the cell cycle (Powell, 1956). Secondly, a lag period of 55 to $60 \mathrm{~min}$ in which no divisions occur must follow the shift-down to $30^{\circ} \mathrm{C}$. This derives from the observation that heat sensitive cells of any age need this time to divide when returned to $30^{\circ} \mathrm{C}$ after a heat shock (Fig. 4). Thirdly, the heat shock must synchronize cells for division. Figure 2 shows that these predictions appear to be fulfilled. An exponential culture growing at $30^{\circ} \mathrm{C}$ was subjected to a $30 \mathrm{~min}$ heat shock at $42{ }^{\circ} \mathrm{C}$ and then returned to $30^{\circ} \mathrm{C}$. Cell division continued at $42{ }^{\circ} \mathrm{C}$ for $20 \mathrm{~min}$ and particle numbers increased by $20 \%$. Viable counts were only $70 \%$ of the particle counts at the shift-up. This probably explains the difference between the particle increase measured $(20 \%)$ and the expected increase $(30 \%)$. The division lag after the shiftdown was $55 \mathrm{~min}$ and at least one synchronous round of division was observed. Cell numbers could not double in this division round because, as stated before, only $70 \%$ of the cells were viable. A control experiment (Fig. 2) with strain MC6, the parental organism of MACr, was done to show that in cells with the $\operatorname{div} A$ wild-type allele, division synchrony was not induced by the heat treatment used to synchronize MACI (certain strains of $E$. coli divide synchronously after a 16 min heat shock at $45^{\circ} \mathrm{C}$; Wu \& Pardee, 1973).

\section{DISCUSSION}

The properties of MACI suggest that the gene mutated in this strain has a role in the timing control of cell division in $E$. coli. This is mainly substantiated by the similarities in the division times ( 55 to $60 \mathrm{~min}$ ) of cells of different ages after a heat shock to inactivate div $A$ product (Figs. 2 and 4). If the only effect of $\operatorname{div} A$ product inactivation was to stop cell progress towards division, the division time of synchronous cultures heated immediately after elution should be $45 \mathrm{~min}$ and that of cultures treated $20 \mathrm{~min}$ later should be $25 \mathrm{~min}$. Inactivated cells shared another property: they required the same time ( 40 to $45 \mathrm{~min}$ ) to perform the thermosensitive function specified by $\operatorname{div} A$ (Fig. 6). Most of this time was probably necessary for gene expression (Fig. 7). According to these results, it appears that when the div $A$ product is inactivated, cells return to the starting point of a clock-like control system of the division cycle. From this point, cell progress to division seems to require a fixed period (between 40 and $45 \mathrm{~min}$ ) in which $\operatorname{div} A$ function is performed and a further period that is independent of $\operatorname{div} A$. This second period takes 20 min under physiological conditions, at a generation time of 50 min (Fig. 3), though it can be reduced to about $15 \mathrm{~min}$ when the cell cycle is disturbed by previous heating (Figs. 4 and 6). This last portion of the division cycle which is not under $\operatorname{div} A$ control, most probably corresponds to the D period (Cooper \& Helmstetter, 1968) as 
indicated by its length and by the fact that cells are able to divide in the presence of CAP or NA during this period (Fig. 5). It is possible that $\operatorname{div} A$ function is related to initiation of the division processes which usually take place during the $\mathrm{D}$ period, by triggering this initiation at the completion of chromosome duplication. However, the $\operatorname{div} A$ control period can be uncoupled from chromosome replication; after inactivation of the $\operatorname{div} A$ product the time of division or the time of the $\operatorname{div} A$ control period was the same in cells which were at different points of chromosome replication. Under physiological conditions, the end of a round of replication and the end of the $\operatorname{div} A$ control period coincide, and the similar time length (40 to $45 \mathrm{~min}$ ) of chromosome replication (Cooper \& Helmstetter, 1968) and the $\operatorname{div} A$ control period suggests that both processes are initiated at the same time. Simultaneous initiation of these processes has not yet been demonstrated. However, it has been proposed that DNA replication and a $40 \mathrm{~min}$ period of protein synthesis necessary for division are initiated approximately simultaneously (Pierucci \& Helmstetter, I969). Again, the similarity between the duration of this protein synthesis period and of the $\operatorname{div} A$ control period, and the fact that these processes are completed simultaneously, tempt us to propose that $\operatorname{div} A$ has an important role in fixing the time for the protein synthesis period necessary for division in E. coli.

Many division-defective mutant strains of $E$. coli have been isolated and described. It is possible that some of them are mutated at the same gene as MACr. This is more probable among those which septate when returned to the permissive temperature, such as PAT84 (Hirota, Ryter \& Jacob, 1968) and Bug6 (Reeve, Groves \& Clark, 1970), or which harbour the thermosensitive mutation between leu and pro as fts $A$ and $C$ (Ricard \& Hirota, 1973) and the AX series (Allen et al. 1974). However, strain ts-20 (Nagai \& Tamura, 1972) has more phenotypic affinities with MACI than any other strain. This mutant also divided synchronously after a heat shock. Phenotypic differences between ts-20 and MACI are also remarkable, the most significant one being that heated cells of ts-20 gained the ability to divide at $42{ }^{\circ} \mathrm{C}$, or in the presence of CAP, I 5 min after the heat shock.

Our data cannot explain the mechanisms for $\operatorname{div} A$ control of division. An appealing hypothesis is that there has to be a minimum amount of $\operatorname{div} A$ product present before the last portion of the division cycle can take place, this product being consumed entirely at a division site when its function is performed. Evidence for the existence of a division factor with such a quantal behaviour has been reported (Teather, Collins \& Donachie, 1974). This hypothesis explains why MACI cells of different ages divided at the same time after a heat shock. If $\operatorname{div} A$ product is totally destroyed, then no matter how much was present in cells (depending on age) before heating, cells have to start the synthesis of $\operatorname{div} A$ product from zero and therefore the time to make the minimum amount is the same in each cell. In favour of this hypothesis is the fact that synthesis of $\operatorname{div} A$ product is not completed until the end of the $\operatorname{div} A$ control period (Fig. 7), and it probably starts early in the cell cycle as suggested by the division delay that heat shock causes even to young cells (Fig. 4).

We thank M. G. Gregorio for helping to isolate thermosensitive defective mutants, and M. J. F. Caberra for technical assistance. This research was supported by grants from Comisión Asesora de Investigación Científica y Técnica, Ill Plan de Desarrollo and Fundación E. Rodriguez Pascual. 


\section{REFERENCES}

ADAMS, M. H. (1959). Bacteriophages. Ist edn, p. 446. New York: Interscience.

Allen, J. S., Filip, C. C., Gustafson, R. A., Allen, R. G. \& Walker, J. R. (I974). Regulation of bacterial cell division: genetic and phenotypic analysis of temperature-sensitive, multinucleate, filament-forming mutants of Escherichia coli. Journal of Bacteriology II7, 978-986.

Cerdá-Olmedo, E., Hanawalt, P. C. \& Guerola, N. (1968). Mutagenesis of the replication point by nitrosoguanidine: map and pattern of replication of the Escherichia coli chromosome. Journal of Molecular Biology 33, 705-7I9.

Clark, D. J. (1968). The regulation of DNA replication and cell division in Escherichia coli B/r. Cold Spring Harbor Symposia on Quantitative Biology 33, 823-828.

COOPER, S. \& Helmstetter, C. E. (1968). Chromosome replication and the division cycle of Escherichia coli B/r. Journal of Molecular Biology 31, 519-540.

Cummings, D. J. (1970). Synchronization of E. coli $\mathrm{KI} 2$ by membrane selection. Biochemical and Biophysical Research Communications 4I, 47I-476.

Helmstetter, C. E. \& Pierucci, O. (1968). Cell division during inhibition of DNA synthesis in Escherichia coli. Journal of Bacteriology 95, 1627-1633.

Hirota, Y., RYter, A. \& JACOB, F. (1968). Thermosensitive mutants of $E$. coli affected in the processes of DNA synthesis and cellular division. Cold Spring Harbor Symposia on Quantitative Biology 33, 677-693.

Jones, N. C. \& DonaChIE, W. D. (1973). Chromosome replication, transcription and control of cell division in Escherichia coli. Nature New Biology 243, 100-103.

Jones, N. C. \& Donachie, W. D. (1974). Protein synthesis and the release of the replicated chromosome from the cell membrane. Nature, London 251, 252-254.

Kammen, H. O. (1967). Thymine metabolism in Escherichia coli. I. Factors involved in utilization of exogenous thymine. Biochimica et biophysica acta 134, 30I-3I I.

Low, B. \& WooD, T. H. (1965). A quick and efficient method for interruption of bacterial conjugation. Genetic Research 6, 300-303.

NaGai, K. \& TAmura, G. (1972). Mutant of Escherichia coli with thermosensitive protein in the process of cell division. Journal of Bacteriology 112, 959-966.

PierUCCI, O. \& Helmstetter, C. E. (I969). Chromosome replication, protein synthesis and cell division in Escherichia coli. Federation Proceedings 28, 1755-1760.

Powell, E. O. (I956). Growth rate and generation time of bacteria, with special reference to continuous culture. Journal of General Microbiology 15, 492-5 I I.

Reeve, J. N., Groves, D. J. \& ClarK, D. J. (I970). Regulation of cell division in Escherichia coli: characterization of temperature-sensitive division mutants. Journal of Bacteriology 104, 1052-1064.

Ricard, M. \& Hirota, Y. (1973). Process of cellular division in Escherichia coli: physiological study of thermosensitive mutants defective in cell division. Journal of Bacteriology Ir6, 314-322.

TAYLOR, A. L. \& TrotTer, C. D. (I972). Linkage map of Escherichia coli strain KI2. Bacteriological Reviews 36, 504-524.

Teather, R. M., Collins, J. F. \& Donachie, W. D. (1974). Quantal behaviour of diffusible factor which initiates setpum formation at potential division sites in Escherichia coli. Journal of Bacteriology rr8, 407-413.

Wu, P. C. \& PARDEe, A. B. (1973). Cell division of Escherichia coli: control by membrane organization. Journal of Bacteriology 114, 603-6I I. 